Article Type: Research Paper

\title{
The Influence of Service Quality, Price, Corporate Image, and Location Towards Customer Satisfaction on Autocare Universitas Muhammadiyah Yogyakarta
}

\author{
Dwi Kurniawati Amini ${ }^{1}$ and Dimas Bagus Wiranatakusuma ${ }^{1}$
}

\begin{abstract}
This study aims to analyze the Influence of Service Quality, Price, Corporate Image, and Location towards Customer Satisfaction on Autocare Universitas Muhammadiyah Yogyakarta. This study uses a quantitative approach. The data used is primary data obtained by distributing questionnaires to the customers of Autocare UMY to 99 respondents. The method of sample collection uses a purposive sampling technique. The technique of data analysis that used in this study to process the data is multiple linear regression. The results of this study indicates that all independent variables namely Service Quality, Price, Corporate Image, and Location has a positive and significant influence on the dependent variable, namely Customer Satisfaction both simultaneously and partially.

Keywords: Service Quality; Price; Corporate Image; Location; Customer Satisfaction.
\end{abstract}

THIS ARTICLE IS AVALILABLE IN:

http://journal.umy.ac.id/index.php/jerss

DOI: $10.18196 /$ jerss.040117

\section{CITATION:}

Amini, D. K., \& Wiranatakusuma, D. B. (2020). The Influence of Service Quality, Price, Corporate Image, and Location Towards Customer Satisfaction on Autocare Universitas Muhammadiyah Yogyakarta. Journal of Economics Research and Social Sciences, 4(1), 30-43.

\section{Introduction}

The number of motorized vehicles in Indonesia continues to surge every year both car and motorcycle. The increase of motorized vehicles occurred in nationally and in regions, especially in the big cities. The increasing number of motorized vehicles can be caused by: there is no regulation from the government regarding the maximum amount of motorized vehicles that owned by society. It happens also due to customers behavior in using motorized vehicles both car or motorcycle.

Table 1 Number of Motorized Vehicles in 2009-2017

\begin{tabular}{|cc|}
\hline Year & Number of Motorized Vehicles \\
\hline 2009 & $67,336,644$ \\
2010 & $76,907,127$ \\
2011 & $85,601,351$ \\
2012 & $94,373,324$ \\
2013 & $104,118,969$ \\
2014 & $114,209,260$ \\
2015 & $121,394,185$ \\
2016 & $129,281,079$ \\
2017 & $138,556,669$ \\
\hline
\end{tabular}

Source: Central Bureau of Statistics 2017 
The increasing in the number of vehicles has a positive impact on the development of businesses that offers the services in the automotive field. Nugraha et., al (2014) stated that entrepreneurs will make this phenomenon as an advantage for the entrepreneur's companies. Where the entrepreneurs will make business in the automotive field. The form of service could be maintenance of vehicles such as car wash and motorcycle wash.

The phenomena increasing the number of motorized vehicles also happen in regionally scale which in Daerah Istimewa Yogyakarta (DIY). Due to this research is conducted in Autocare Universitas Muhammadiyah Yogyakarta which one of the business units that built by Universitas Muhammadiyah Yogyakarta. Autocare UMY is a business that is in the automotive field. It offered the vehicle's maintenance such as car wash, motorcycle wash and carpet wash. The existence of Autocare UMY itself can gain the benefit for Universitas Muhammadiyah Yogyakarta. It happens due to the revenue of UMY will not only from the tuition fee that the students paid for every semester. Moreover, the revenue will also be obtained from the non-tuition fee which from the business units of UMY where Autocare UMY is one of them.

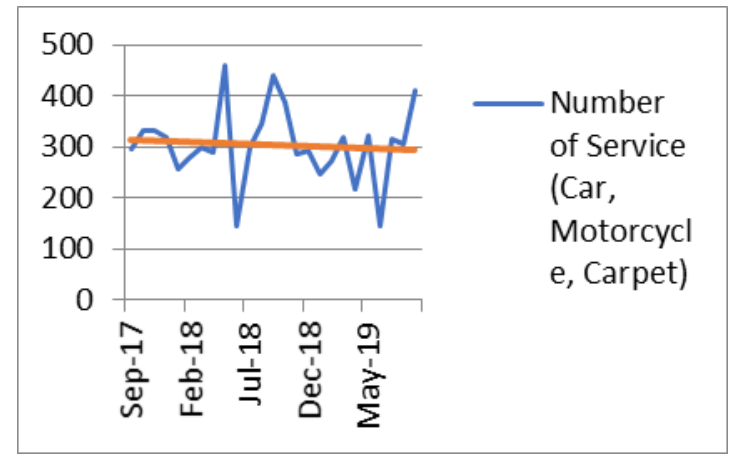

Figure 1 Trend Graph of Number of Service Customers

Source: Autocare Universitas Muhammadiyah Yogyakarta

The figure 1 shows the fluctuation of customers of Autocare UMY that happens in September 2017 to September 2019. It can be seen the red line shows the trend line number of customers on Autocare UMY which is moving downwards. While, in the Universitas Muhammadiyah Yogyakarta there are lots of motorized vehicles that owned by the lecturers, students, and employees of UMY. Where it can be a good chance for Autocare UMY to get the customer who wants to maintain their cars or motorcycles.

Based on fluctuations in the number of customers that occur on Autocare UMY, the Autocare party needs to pay attention to the factors that drive the increase and decrease in the number of customers who use the Autocare UMY service. Based on the background that the author has previously described, the author is interested in conducting research to determine the factors that influence customer satisfaction. In this research, the factors that used are service quality, price, corporate image, and location. 


\section{Literature Review and Hypotheses Development}

\section{Marketing Management}

Marketing management is a social and managerial process that makes individuals and groups get what they need and want through the creation and exchange of products and values with others (Rahayu and Fathoni, 2017). Marketing activities must be able to bring customers closer, examine market opportunities, determine the position of the service market segments and target markets based on the needs of the services and formulate a marketing mix (Sukotjo \& Sumanto, 2010). The intended marketing mix is 7 $\mathrm{P}$ (product, price, promotion, place, people, process, and physical evidence).

Marketing is the most important activity of a company. It is because of marketing makes the customers able to meet their needs through the products both goods or services that sell by the company as the seller. The company should fulfill the satisfaction of the customers on the process of marketing activity (Nurhalimah et., al, 2018).

\section{Service Quality}

According to Tjiptono in Kuntari et al. (2016) "service quality is a comparison between service perceived by customers (perception) with service quality expected by customers". Meanwhile, according to Pontoh et., al (2014), service quality is defined as an effort to meet the needs and desires of customers and the accuracy of their delivery in balancing customer expectations. So, service quality is a way or strategy for a company to deliver a service to its customers in order to satisfy the customer.

Goofin and Price (1996) in Jahanshahi et., al (2011) stated that service is important. By increasing product quality the company will have a competitive advantage. In addition, the company will get opportunities to increase sales and revenues. Budi Harto (2015) in his research stated that service quality is very dependent on 3 (three) things. This is in the form of systems, technology, and people. If the company has a good work system, utilizes advanced technology, and quality standards of qualified workers in their field, then the company can make good quality service standards. Lupiyoadi in Krisdayanto, Iqbal et., al (2018) in his research state that there are 5 (five) dimensions of service quality that must be fulfilled, namely tangibles, empathy, reliability, responsiveness, and assistance.

\section{Price}

Daryanto in Suryonaningsih et., al (2016) states the price is the amount of money billed by the company to customers. Whereas, Rares and Jorie (2015) said that the price is also the amount of money needed by the community to get a combination of products (goods and services) and its services. Based on the definition of price, then the price is the amount of money that shows the value of a product in the form of goods or services. 
Before deciding to get or buy an item or service, the public will assess the price of the product at first. Where the price of a product must match the quality that the product has. Then, customers will decide to give up their money to buy the product. So, price becomes one of the important things in determining for a product to sell. Ferdinand in Arviantama (2016) stated that price is one of the important variables in marketing. Therefore, a company needs to build a business strategy that can make customers and companies profitable.

Price is a good strategy to get profit for the company (Listyawati, 2018). This can be done by making competitive price standards and also in line with product quality standards. If the price is set too high, then customers will be reluctant to give up some of their money to own or enjoy a product. Vice versa, when the price of a product is relatively low, then customers will assume that the quality of the product is not so good.

\section{Corporate Image}

Pontoh et., al (2014) mentions that an image is a reflection of the identity of an organization or company. Company image according to Normasari et., al (2013) is a representation of an institution with the hope of being able to encourage a positive image. Meanwhile, according to Kotler and Keller in Kartika and Kuswandiro (2019), that a corporate image is a set of beliefs, ideas, and impressions that a person has of an object. From the explanation, it can be concluded that the corporate image is a customer's view of the impression given by the company.

Tuuk et., al (2019) stated that the image would reflect the company's level of commitment to quality, excellence, and also relationships with customers and partners. In this case, the corporate image helps facilitate customer knowledge on the products offered by the company. There are 4 parts of the company image stated by Liou \& Chuang in Tjandra, Olivia et., al (2016), including morality, management, performance, and service.

\section{Location}

Location means the location of a building in an area, where the company will operate. Rares and Jorie (2015) stated that location is a strategic location which is easily accessible by customers. The location will also affect the number and type of customers who will be attracted to come to a strategic location.

Location can affect the company's existence in the future. In addition, the location of the company must be able to provide benefits to the company. This is in line with research conducted by Krisdayanto, Iqbal et., al (2018), that the factors that must be considered in determining the strategic location of a company, namely: Access, visibility, traffic, large and secure parking area, expansion, environment, competition. 


\section{Customer Satisfaction}

Customer satisfaction is the taste felt by customers after receiving a service. Customer satisfaction will be achieved when the desires and needs of customers are met in accordance with customer expectations. This expectation is the confidence of customers on the performance of services to be provided by the company. As stated by Suryonaningsih et., al (2016) in his research, that customers will experience various levels of satisfaction and dissatisfaction after experiencing services in accordance with customer expectations.

Customer satisfaction is the level of one's feelings after comparing performance with expectations expressed Daryanto in Suryonaningsih et., al (2016). Meanwhile, according to Nurhalimah et., al (2018) customer satisfaction or dissatisfaction is part of the experience experienced by customers of a product offered by the company. So with that experience customers have a tendency to build certain values.

The company must be oriented to customer satisfaction by meeting customer expectations. In addition, the company must prepare its workers to be able to serve customers properly and correctly. Therefore, a measure of customer satisfaction is very beneficial for the company in order to evaluate company performance. This can make the company compete with its competitors and the company can evaluate their performance according to the views of Susilo, et., al (2018).

\section{Research Method}

The object of this research is Autocare Universitas Muhammadiyah Yogyakarta. While the subject of this research is the people of Universitas Muhammadiyah Yogyakarta (UMY) and the general public outside UMY environment. The data of this research is primary data that obtained directly from the respondent by distributing the questionnaire. Furthermore, the data is analysed with multiple linear regression to determine the influence of independent variables namely service quality, price, corporate image, and location. While the dependent variable is customer satisfaction. Multiple linear regression model is:

$$
Y_{t}=a+\beta_{1} X_{1 t}+\beta_{2} X_{2 t}+\beta_{3} X_{3 t}+\beta_{4} X_{4 t}+e_{t}
$$

Explanation:

$\begin{array}{ll}Y_{t} & =\text { Customer Satisfaction } \\ a & =\text { The constant } \\ \beta_{1}, \beta_{2}, \beta_{3}, \beta_{4} & =\text { Regression coefficient } \\ X_{1 t} & =\text { Service Quality } \\ X_{2 t} & =\text { Price } \\ X_{3 t} & =\text { Corporate Image } \\ X_{4 t} & =\text { Location } \\ e_{t} & =\text { Error term }\end{array}$


This study uses no-probability sampling with a purposive sampling technique to determine respondents. The number of respondents in this study were 99 people who obtained from the calculation of the Slovin formula. Slovin formula used to determine the sample size of a study in which the population size of the study is known with $10 \%$ standard of error (Amirin, T.M, 2011). The population of this research is customers of Autocare UMY, as many as 7,610 people. Slovin formula:

$$
\begin{gathered}
n=\frac{N}{1+\left(N \times 0,1^{2}\right)} \\
n=\frac{7.610}{1+\left(7.610 \times 0,1^{2}\right)} \\
n=98,70
\end{gathered}
$$

The result of Slovin formula is 98,70 then rounded to 99 . So, the sample size of this research are 99 respondents.

\section{Result and Discussion}

\section{A. Validity and Reliability Test}

Validity test is done by looking at the value of KMO (Keiser-Meyer-Olkin) is higher than 0,50 , the anti-image's value is higher than 0,50 and the factor of loading of instruments is higher than 0,50, it means that the instrument is valid (Basuki and Imamudin, 2017). Furthermore, the value of KMO (Keiser-Meyer-Olkin) for this data of research is higher than 0,50 . While the anti-image's value is also higher than 0,50 . Then, the factor of the loading instrument is more than 0,50 .

According to Ferdinand (2014), this reliability test aims to measure the consistency of answers to the questionnaire. Where the value of Cronbach Alpha $\geq 0.60$. for the data of this research, the value of Cronbach Alpha is more than 0.60 . Then, the data of this research is reliable

\section{B. Result of Classical Assumption}

\section{a. Normality Test}

Table 2 The Result of Normality Test

\begin{tabular}{llr}
\hline $\mathrm{N}$ & & Unstandardized Residual \\
\hline Normal Parameters & Mean & 99 \\
& Std. Deviation & .0000000 \\
& Absolute & 1.27313102 \\
Most Extreme Differences & Positive & .079 \\
& Negative & .069 \\
Kolmogorov-Smirnov Z & & -.079 \\
Asymp.Sig. (2-tailed) & & .785 \\
\hline
\end{tabular}


Table 2 shows the value of Kolmogorov-Smirnov significant is more than $5 \%$ (0.569 > $0,05)$. It indicates that the variables used in this research is distributed normally or do not contain normality problem.

\section{b. Heteroscedasticity Test}

Table 3 shows the number of significant for every independent variable is higher than $5 \%$. Service quality has 0.343 , the price has 0.141 , the corporate image has 0.646 , and the location has 0.789 . Then, it can be concluded that concluded that each independent variables used does not contain heteroscedasticity problems

Table 3 The Result of Heteroscedasticity Test

\begin{tabular}{|c|c|c|c|c|c|c|}
\hline \multirow{2}{*}{\multicolumn{2}{|c|}{ Model }} & \multicolumn{2}{|c|}{$\begin{array}{l}\text { Unstandardized } \\
\text { Coefficients }\end{array}$} & \multirow{2}{*}{$\begin{array}{c}\text { Standardized } \\
\text { Coefficients } \\
\text { Beta }\end{array}$} & \multirow[t]{2}{*}{$\mathrm{t}$} & \multirow[t]{2}{*}{ Sig } \\
\hline & & B & Std. Error & & & \\
\hline \multirow[t]{5}{*}{1} & (Constant) & .595 & .943 & & .631 & .530 \\
\hline & Service Quality & .055 & .058 & .121 & .953 & .343 \\
\hline & Price & -.071 & .048 & -.181 & -1.486 & .141 \\
\hline & Corporate Image & .026 & .057 & .060 & .461 & .646 \\
\hline & Location & .013 & .052 & .035 & .257 & .798 \\
\hline
\end{tabular}

\section{c. Multicollinearity Test}

Table 4 The Result of Multicollinearity Test

\begin{tabular}{|c|c|c|c|}
\hline \multicolumn{2}{|c|}{ Model } & \multicolumn{2}{|c|}{ Collinearity Statistics } \\
\hline & & Tolerance & VIF \\
\hline \multirow[t]{5}{*}{1} & (Constant) & & \\
\hline & Service Quality & .637 & 1.569 \\
\hline & Price & .696 & 1.437 \\
\hline & Corporate Image & .599 & 1.670 \\
\hline & Location & .561 & 1.784 \\
\hline
\end{tabular}

The result of the multicollinearity test shows the number of tolerance for every independent variables are greater than 0.1. As for the value of the Variance Inflation Factors (VIF) of each independent variable has a value smaller than 10 . This shows that each independent variable used in this study does not have a correlation with each other.

\section{Result of Multiple Linear Regression}

Table 5 The Result of Multiple Linear Regression Test

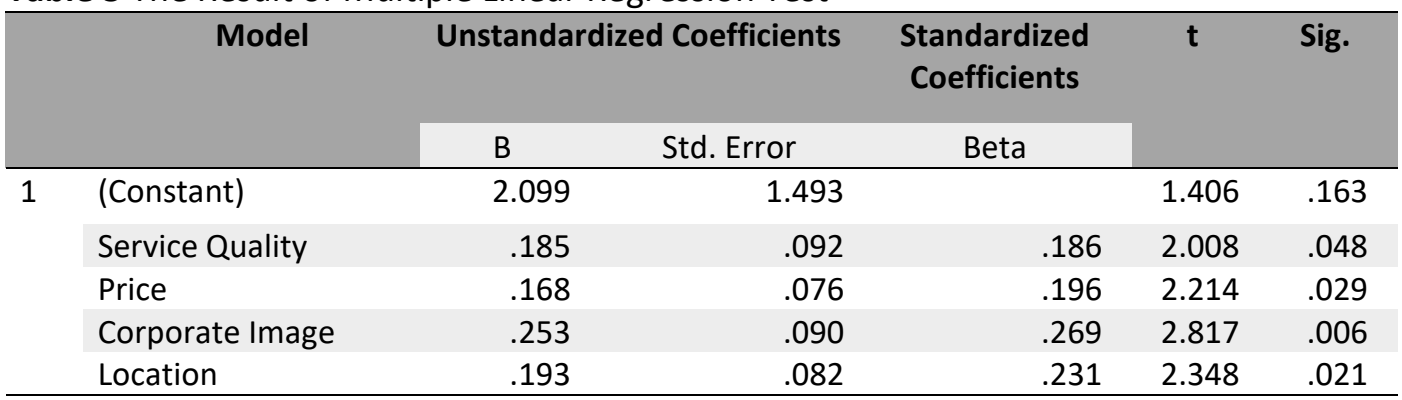


The coefficient value of each variable can be seen in the Beta column in table 5 , where the independent variable, namely service quality has a regression coefficient of 0.186 , a price of 0.196 , corporate image of 0.269 , and location of 0.231 . While the significant value of each variable shows less than 0.05 , then each independent variable has a significant effect on the dependent variable which is customer satisfaction. Then the regression equation that is formed is as follows:

$$
Y=0,186 X_{1}+0,196 X_{2}+0,269 X_{3}+0,231 X_{4}
$$

\section{The Result of Hypothesis Test}

\section{a. Determination Coefficient Test $\left(\mathbf{R}^{2}\right)$}

Table 6 The Result of Determination Coefficient Test $\left(R^{2}\right)$

\begin{tabular}{ccccc}
\hline \multicolumn{2}{c}{ Model } & $\mathbf{R}$ & $\mathrm{R}$ Square & $\begin{array}{c}\text { Adjusted } \mathbf{R} \text { Square } \\
\text { Estimate }\end{array}$ \\
\hline 1 & .698 & .488 & .466 & $\begin{array}{c}\text { Std. Error of the } \\
\text { Estima }\end{array}$ \\
\hline
\end{tabular}

Based on the coefficient of determination $\left(R^{2}\right)$, it shows that the independent variables used in this study are Service Quality $\left(X_{1}\right)$, Price $\left(X_{2}\right)$, Corporate Image $\left(X_{3}\right)$, and Location $\left(X_{4}\right)$ can explain the dependent variable namely Customer Satisfaction $(Y)$ of $46.6 \%$. While $53,4 \%$ is explained by other variables outside the variables used in this study.

\section{b. F Test}

Table 7 The Result of F Test

\begin{tabular}{|c|c|c|c|c|c|c|}
\hline & Model & Sum of Squares & $\overline{\text { Df }}$ & $\begin{array}{l}\text { Mean } \\
\text { Square }\end{array}$ & $F$ & Sig. \\
\hline \multirow[t]{3}{*}{1} & Regression & 151.176 & 4 & 37.794 & 22.365 & .000 \\
\hline & Residual & 158.845 & 94 & 1.690 & & \\
\hline & Total & 310.020 & 98 & & & \\
\hline
\end{tabular}

The significant value that shows on $\mathrm{F}$ test shows that the significant value is less than 0.05 or $5 \%$ where the significant value is 0,000 . It means the independent variables namely Service Quality $\left(X_{1}\right)$, Price $\left(X_{2}\right)$, Corporate Image $\left(X_{3}\right)$, and Location $\left(X_{4}\right)$ have a significant influence on the dependent variable, namely Customer Satisfaction $(\mathrm{Y})$ simultaneously.

\section{c. T Test}

Table 8 The Result of T Test

\begin{tabular}{llrrrrr}
\multicolumn{1}{c}{ Model } & Unstandardized Coefficients & \multicolumn{2}{c}{$\begin{array}{c}\text { Standardized } \\
\text { Coefficients }\end{array}$} & t & Sig. \\
& & B & Std. Error & Beta & \\
\hline 1 & (Constant) & 2.099 & 1.493 & .406 & .163 \\
& Service Quality & .185 & .092 & .186 & 2.008 & .048 \\
& Price & .168 & .076 & .196 & 2.214 & .029 \\
& Corporate Image & .253 & .090 & .269 & 2.817 & .006 \\
& Location & .193 & .082 & .231 & 2.348 & .021 \\
\hline
\end{tabular}


Based on the results of the T test to test the hypothesis in table 8 , it can be concluded that:

a) $\mathrm{H}_{1}=$ The $t$-value for service quality $\left(X_{1}\right)$ is 2,008 where the value is positive. While, the significant value is lower than $0,05(0.048<0,05)$. So, it can be concluded that service quality has a positive and significant effect on Customer Satisfaction.

b) $\mathrm{H}_{2}=$ The $t$ test results, shows the $t$ value for price $\left(\mathrm{X}_{2}\right)$ is 2.214 where the value is positive. Meanwhile, the significant value is 0.029 where it is lower than 0,05 . Then, it can be concluded that the price has a positive and significant effect on customer satisfaction.

c) $\mathrm{H}_{3}=$ From the $T$ test results, it can be seen that the $t$ value for corporate image $\left(X_{3}\right)$ is 2.817 where the value is positive. Then, the significant value owned by the corporate image is 0.006 , where it is smaller than 0.05 . So, it can be concluded that the corporate image has a positive and significant effect on customer satisfaction.

d) $\mathrm{H}_{4}=$ From the result it shows the value of $t$ for the location $\left(\mathrm{X}_{4}\right)$ of 2.348 where the value is positive. The significant value of the location is 0.021 less than 0.05 . So, it can be said that the location variable has a positive and significant effect on customer satisfaction.

Based on the result of data analysis, it can be concluded that:

\section{Service Quality has Positive and Significant Influence towards Customer Satisfaction}

Table 5 shows the Beta coefficient value owned by the service quality variable of 0.186 which is positive. If the service quality variable increases by 1 unit, then the customer satisfaction variable will increase by 0.186 . Meanwhile, the significant value of 0.048 is smaller than 0.05 . So, service quality has a positive and significant effect on customer satisfaction.

The results of this study indicate that the quality of services provided by the Autocare Universitas Muhammadiyah Yogyakarta (Autocare UMY) is in accordance with customer expectations. By fulfilling the hopes and desires of customers, then satisfaction can be felt by customers. In accordance with that described by Pontoh et., Al (2014). This can be seen from the customer good perception of the indicators used to represent the variable quality of service provided by Autocare UMY. The indicators used to represent service quality variables in this study are fast service, ease of transaction, understanding customer needs, and shuttle services performed by Autocare UMY employees.

These things indicate the ability of the Autocare UMY in providing services to customers is good. The better the quality of the services provided, the customer will feel satisfied. The similar result of research has been done by Nurhalimah, S. et., al (2018), Susilo, Heri et., al (2018), Annamdevula, S. and Bellamkonda, R.S. (2016), Xu, Lu et., al (2017), and Zameer, Hashim et., al (2015). 


\section{Price has Positive and Significant Influence towards Customer Satisfaction}

Beta regression coefficient values indicate the price variable has a positive value that is equal to 0.196 . If the variable price rises by 1 unit, then customer satisfaction will increase by 0.196 . Then, a significant value of 0.029 which is smaller than 0.05 . Thus, price variables have a positive and significant effect on customer satisfaction.

Price is the amount of money exchanged for products or services to get benefits from the product or (Iriyanti, E. et., al, 2016). This research shows that the tariff or price set by the Autocare Universitas Muhammadiyah Yogyakarta is in accordance with the ability of customers to pay for services and market prices. This is in line with research conducted by Arviantama et., al (2017).

There are indicators that can represent the price variable itself. Where customer perception of these indicators are good. The indicators in question are the price according to the type of service, the price of each competitive service where the price set by Autocare UMY can compete with the market price, and the price is in accordance with the benefits obtained. If customers' perceptions about the indicators are good, then the overall price at Autocare UMY is in accordance with customer desires and the ability of customers to pay for services. These findings are in line with some studies by Razak, I. et., al (2016), Nurhalimah, Siti et., al (2018), Susilo, Heri et., al (2018), Ferandi, S.M. et., al (2016), Namin, Aidin (2017), Hanaysha, Jalal (2016), and Khuong and Dai (2016).

\section{Corporate Image has Positive and Significant Influence towards Customer Satisfaction}

The regression coefficient value of the corporate image variable in the Beta column is 0.269. If the corporate image variable increases by 1 unit, then the variable customer satisfaction will increase by 0.269 . Then, the significant value is 0.006 . This shows the corporate image has a positive and significant effect on customer satisfaction.

Corporate image is the view or perception of customers towards a company (Pontoh et., al., 2014). The results of this study explain that the image of the Autocare Universitas Muhammadiyah Yogyakarta is good. The better the image of a company, the more customers will be interested in using the product or services of a company.

The perception of the customer towards the image held by Autocare UMY cannot be separated from the indicators that represent the variable of the corporate image. These indicators are the corporate good reputation, the name of the company that is easy to remember, the company can be trusted by customers, and good quality owned by the company. If the customer response is good to these indicators, then the overall image held by Autocare UMY will be good. Similar research results were also conducted by Tjandra, Olivia et., al (2016), Saktiani, G.A. (2015), and Zameer, Hashim, et., al (2015). 


\section{Location has Positive and Significant Influence towards Customer Satisfaction}

The result of the regression coefficient of the location variable in the Beta column of 0.231 . If the location variable increases by 1 unit, then the location variable will increase by 0.231 . Meanwhile, the significant value of the location variable is 0.021 . Then, it can be concluded that location has a positive and significant influence on customer satisfaction.

The results of this study indicate that the Autocare location of Universitas Muhammadiyah Yogyakarta influences customer satisfaction. A location is a place where a company carries out sales or manufacturing activities of goods or services (Atmanegara, et., al, 2019). So, determining the location of a company is important for the future of the company. The better and strategic location of Autocare UMY, the easier it will be for customers to meet their needs, in this case, the vehicle maintenance needs. When the needs of customers are met then there will be a sense of satisfaction in customers because of the ease in accessing the location of the company.

The existence of a positive and significant relationship of location variables to the variable customer satisfaction can not be separated from good customer perceptions of indicators that can represent the location. These indicators are a safe company environment, easily accessible location, location can be reached by transportation, and the location is easy to find. If customers' perceptions are good for these indicators, it can be concluded that customer perceptions of location variables are also good. The same research was also carried out by Krisdayanto, Iqbal et., al (2016), Ferandi, S.M. et., al (2016), and Nurhalimah, Siti et., al (2018).

\section{Conclusion}

Based on the results of data analysis that has been carried out on all data obtained, the independent variables that used on this research, namely service quality $(X 1)$, price $(X 2)$, corporate image (X3), and location (X4) has positive and significant influence towards customer satisfaction ( $Y$ ) in simultaneously and partially. (1) Service quality has positive and significant influence towards customer satisfaction. It happens due to the good perception of the services speed, ease of transaction, employee understanding to the customer, and shuttle service by employees. (2) Price has a positive and significant effect on customer satisfaction. It happens due to a good perception of the price is in accordance with the service, price is competitive, price is affordable, and the price is equal to the benefit obtained. (3) The corporate image has a positive and significant effect on customer satisfaction. It happens because of the good perception of company reputation, the company name is easy to remember, the company can be trusted, and the quality of the company. (4) The location has a positive and significant impact on customer satisfaction. It happens because of the good perception to Autocare UMY environment, ease of accessing location, ease of accessing location with the transportation, and ease of finding the location. 


\section{References}

Amirin, T. M. (2011). Populasi dan sampel penelitian 4: Ukuran sampel rumus Slovin. Retrieved from http://tatangmanguny.wordpress.com/2010/04/19/ukuran-sampelrumus-slovin/

Annamdevula, S., \& Bellamkonda, R. S. (2016). The effects of service quality on student loyalty: the mediating role of student satisfaction. Journal of Modelling in Management, 11(2), 446-462. https://doi.org/10.1108/JM2-04-2014-0031

Arviantama, A., Hasiholan, L. B., Purwana, E. G., \& Darsin. (2016). Peningkatan kualitas pelayanan, fasilitas dan harga untuk kepuasan pelanggan agar tercipta loyalitas pelanggan (Studi pada pelanggan gedung DPPPKAD kabupaten Semarang). Journal of Management, 3(3). Retrieved from https://jurnal.unpand.ac.id/index.php/MS/article/view/747

Atmanegara, S. Y., Cahyono, D., Qomariah, N., \& Sanosra, A. (2019). Pengaruh kualitas pelayanan, citra perusahaan, dan lokasi terhadap kepuasan konsumen Hotel Ijen View Bondowoso. JSMBI (Jurnal Sains Manajemen Dan Bisnis Indonesia), 9(1), 79-89. https://doi.org/10.32528/jsmbi.v9i1.2375

Badan Pusat Statistik Yogyakarta. (2018). Retrieved October 2019

Basuki, A. T., \& Imamudin. (2017). Pengolahan Data Elektronik(SPSS 15 dan Eviews 7). Yogyakarta: Danisa Media.

Ferandi, S. M., Prabawani, B., \& Ngatno. (2016). Pengaruh kualitas pelayanan, harga, dan lokasi terhadap keputusan menggunakan jasa service mobil (Studi kasus pada konsumen PT. Sun Star Motor Banyumanik Semarang). Jurnal Ilmu Administrasi Bisnis, 5(3), 272-281. Retrieved from https://ejournal3.undip.ac.id/index.php/jiab/article/view/12335

Hanaysha, J. (2016). Testing the effect of food quality, price fairness, and physical environment on customer satisfaction in fast food restaurant industry. Joumal of Asian Business Strategy, 6(2), 31-40. https://doi.org/10.18488/journal.1006/2016.6.2/1006.2.31.40

Harto, B. (2015). Analisis tingkat kepuasan pelanggan dengan pendekatan fuzzy servqual dalam upaya peningkatan kualitas pelayanan (Studi kasus di bengkel resmi BAJAJ Padang). Jurnal TEKNOIF, 3(1). http://dx.doi.org/10.21063\%2Fitif.2015.V3.1.

Iriyanti, E., Qomariah, N., \& Suharto, A. (2016). Pengaruh harga, kualitas produk, dan lokasi terhadap loyalitas pelanggan melalui kepuasan sebagai variabel intervening pada depot mie pangsit Jember. Jurnal Manajemen Dan Bisnis Indonesia, 2(1). https://doi.org/10.32528/imbi.v2i1.1211

Jahanshahi, A. A., Gashti, M. A., Mirdamadi, S. A., Nawaser, K., \& Khaksar, S. M. (2011). Study the Effects of Customer Service and Product Quality on Customer Satisfaction and Loyalty. International Journal of Humanities and Social Science, 1(7). Retrieved from https: / $/$ www.google.com/url? $\mathrm{sa}=\mathrm{t} \& \mathrm{rct}=\mathrm{i} \& \mathrm{q}=\& \mathrm{esrc}=\mathrm{s} \& \mathrm{source}={ }_{\mathrm{web}} \& \mathrm{~cd}=\& \mathrm{cad}=\mathrm{rja}$ \&uact $=8$ \&ved $=2$ ahUKEwilr5GVdXqAhUCjeYKHYeVDEEQFjAAegQIBBAB\&url=http $\% 3 \mathrm{~A} \% 2 \mathrm{~F} \% 2 \mathrm{Fwww.ijhssnet.}$ com\%2Fjournals $\% 2 F V$ ol. 1 No. $7 \% 5$ BSpecial Issue June 2011\%5D\%2F33.pdf\& usg=AOvVaw15kCg0B0AzY1usgSf6sJJx

Kartika, C., \& Kuswandiro, D. A. (2019). Pengaruh citra perusahaan dan gaya hidup terhadap niat pembelian melalui kepuasan pelanggan sebagai variabel intervening. Develop, 3(2), 1-20. Retrieved from https:// ejournal.unitomo.ac.id/index.php/ep/article/view/1789/902

Khuong, M. N., \& Dai, N. Q. (2016, October). The Factors Affecting Customer Satisfaction and Customer Loyalty A Study of Local Taxi Companies in Ho Chi Minh City, 
Vietnam. International Journal of Innovation, Management and Technology, 7(5), 228-233.

Retrieved from

http:/ $/$ www.ijimt.org $/$ index.php? $\mathrm{m}=$ content\&c $=$ index $\& a=$ show\&catid $=76 \& \mathrm{did}=1012$

Krisdayanto, I., Haryono, A. T., \& PT, E. G. (2018). Analisis pengaruh harga, kualitas pelayanan, fasilitas, dan lokasi terhadap kepuasan konsumen di I Cafe Lina Putra Net

Bandungan. Journal of Management, 4(4). Retrieved from https://jurnal.unpand.ac.id/index.php/MS/article/view/1025

Kuntari, B. D., Kumadji, S., \& Hidayat, K. (2016). Pengaruh kualitas pelayanan terhadap epuasan dan loyalitas pelanggan (Survei pada pelanggan bengkel PT Astra International Tbk - Daihatsu Malang). Jurnal Administrasi Bisnis (J AB), 36 (1). Retrieved from http://administrasibisnis.studentjournal.ub.ac.id/index.php/jab/article/view/1417

Listyawati, I. H. (2018). Pengaruh kepuasan pelanggan, citra merek, harga dan kualitas produk terhadap loyalitas pelanggan pada handphone Xiaomi di Yogyakarta. Jurnal Bisnis Teori dan Implementasi, 9(1), 37-45. https://doi.org/10.18196/bti.91098

Namin, A. (2017). Revisiting customers' perception of service quality in fast food restaurants. Journal of Retailing and Consumer Services, 34, 70-81. Retrieved from https://econpapers.repec.org/article/eeejoreco/v 3a34 3ay 3a2017 3ai 3ac 3ap 3a 70-81.htm

Normasari, S., Kumadji, S., \& Kusumawati, A. (2013). Pengaruh kualitas pelayanan terhadap kepuasan pelanggan, citra perusahaan dan loyalitas pelanggan (Survei pada tamu pelanggan yang menginap di Hotel Pelangi Malang). Jurnal Administrasi Bisnis (JAB), 6(2). Retrieved from http://administrasibisnis.studentjournal.ub.ac.id/index.php/jab/article/view/286

Nugraha, R., Harsono, A., \& Adianto, H. (2014). Usulan Peningkatan Kualitas Pelayanan Jasa pada Bengkel "X" Berdasarkan Hasil Matrix Importance-Performance Analysis (Studi Kasus di Bengkel AHASS PD. Sumber Motor Karawang). Jurnal Online Institut Teknologi Nasional, 1(3). Retrieved from https:// ejurnal.itenas.ac.id/index.php/rekaintegra/article/view/279

Nurhalimah, S., Hasiholan, L. B., \& Harini, C. (2018). Analisis Pengaruh Kualitas Pelayanan, Harga, dan Lokasi terhadap Kepuasan Pelanggan (Studi pada Bengkel Unggaran). Journal of Management, 4(4). Retrieved from https://jurnal.unpand.ac.id/index.php/MS/article/view/1139

Pontoh, M. B., Kawet, L., \& Tumbuan, W. A. (2014). Kualitas layanan, citra perusahaan dan kepercayaan pengaruhnya terhadap kepuasan nasabah bank BRI cabang Manado. Jurnal EMBA, 2(3), 285-297. https://doi.org/10.35794/emba.v2i3.5502

Rahayu, D. R., \& Fathoni, A. (2017). Analisis Tingkat Kepuasan Konsumen terhadap Kualitas Pelayanan Hotel (Studi Kasus pada Hotel Gumaya di Semarang). Journal of Management, 3(3), 1-8. Retrieved from https://jurnal.unpand.ac.id/index.php/MS/article/view/728

Rares, A., \& Jorie, R. J. (2015). The effect of the price, promotion, location, brand image and quality products towards the purchase desicion of consumers at bengkel Gaoel Store Manado Toen Square. Jurnal EMBA, 3(2), 592-604. https://doi.org/10.35794/emba.v3i2.8591

Razak, I., Nirwanto, N., \& Triatmanto, B. (2016). The Impact of Product Quality and Price on Customer Satisfaction with the Mediator of Customer Value. Journal of Marketing and Consumer Research, 30, 59-68. Retrieved from https://iiste.org/Journals/index.php/JMCR/article/view/34735 
Saktiani, G. A. (n.d.). Pengaruh kualitas layanan dan citra perusahaan terhadap kepuasan pelanggan dan word of mouth. JISIP: Jurnal Ilmu Sosial dan Ilmu Politik, 4(2). Retrieved from https://publikasi.unitri.ac.id/index.php/fisip/article/view/114

Sukotjo, H., \& A., S. R. (2010). Analisa Marketing Mix-7P(Produk, Price, Promotion, Place, Partisipant, Process, dan Physical Evidence) terhadap Keputusan Pembelian Produk Klinik Kecantikan Teta di Surabaya. Jurnal Mitra Ekonomi dan Manajemen Bisnis 1 (2), 216-228. Retrieved from https://scholar.google.co.id/scholar?oi=bibs\&cluster=14044554848814236434\&btnI $=1 \& h l=\mathrm{en}$

Suryonaningsih, E., Paramita, P. D., \& Hasiholan, L. B. (2016). Effect of price and image brand on consumer satisfaction with buying decision as intervening (Study at gamis clothes consumer in Toko Lana Semarang). Journal of Management, 2(2). https://jurnal.unpand.ac.id/index.php/MS/article/view/579

Susilo, H., Haryono, A. T., \& W, M. M. (2018). Analisis pengaruh harga, kualitas pelayanan, promosi, dan kepercayaan terhadap kepuasan konsumen dengan keputusan berkunjung sebagai variabel intervening di hotel Amanda Hills Bandungan. Journal of Management, 4(4). https://jurnal.unpand.ac.id/index.php/MS/article/view/989

Tjandra, O., Andriani, G. E., Kaihatu, T. S., \& Nugroho, A. (2016). Analisa pengaruh citra perusahaan terhadap loyalitas pelanggan melalui kepuasan pelanggan sebagai variabel perantara di restoran Boncafe Surabaya. Jurnal Hospitality dan Manajemen Jasa 4 (1), $37-$ 51. Retrieved from http://publication.petra.ac.id/index.php/manajemenperhotelan/article/view/4129

Tuuk, J. F., Sepang, J. L., \& Karuntu, M. M. (2019). Pengaruh pelayanan, produk, dan citra perusahaan terhadap kepuasan konsumen mobil merk Toyota di Manado. Jurnal EMBA, 7(4), 4710-4719. https://doi.org/10.35794/emba.v7i4.25418

Umat UMY Autocare. (n.d.). Retrieved from http://autocare.umatumy.com

Xu, L., Blankson, C., \& Prybutok, V. (2017). Relative Contributions of Product Quality and Service Quality in the Automobile Industry. Quality Management Journal, 24(1), 21-36. https://doi.org/10.1080/10686967.2017.11918498

Zameer, H., Tara, A., Kausar, U., \& Mohsin, A. (2014). Impact of service quality, corporate image and customer satisfaction towards customers' perceived value in the banking sector in Pakistan. International Journal of Bank Marketing, 33(4), 442-456. Retrieved from https://www.emerald.com/insight/content/doi/10.1108/IJBM-01-2014$\underline{0015 / \mathrm{full} / \mathrm{html}}$ 